\title{
Differing effects of pectin, cellulose and lignin on stool pH, transit time and weight
}

\author{
BY LYBUS HILLMAN, SUE PETERS, ANNE FISHER \\ AND E. W. POMARE* \\ Department of Medicine, Wellington Clinical School, University of Otago, New Zealand
}

(Received 5 October 1982 - Accepted 7 March 1983)

1. Randomized cross-over studies were undertaken to determine the effects of daily dietary supplements of pectin $(12 \mathrm{~g} / \mathrm{d})$, cellulose $(15 \mathrm{~g} / \mathrm{d})$ and lignin $(12 \mathrm{~g} / \mathrm{d})$ on stool characteristics of healthy volunteers.

2. Detailed dietary records were kept throughout the study. Stool collections over $48 \mathrm{~h}$ were used to determine mean stool $\mathrm{pH}$ and weight. The single stool transit time was measured using radio-opaque markers.

3. Pectin did not significantly alter the mean stool $\mathrm{pH}$, transit time or $24 \mathrm{~h}$ wet weight.

4. Cellulose lowered the mean stool pH from 6.38 to 6.12 , decreased mean stool transit time by $27 \%$ and increased mean wet stool weight by $57 \%$.

5. Lignin lowered the mean $\mathrm{pH}$ from $6 \cdot 34$ to $6 \cdot 25$, decreased the stool transit time by $20 \%$ and increased stool weight by $27 \%$ but these changes were not statistically significant.

6. These findings have shown that individual fibre components have different colonic metabolic effects and support the view that associations between dietary fibre intakes and diseases such as colorectal cancer should be evaluated with regard to the type of fibre components consumed.

The possible relationship between dietary fibre ingestion and colorectal cancer is complex and has recently been reviewed by Spiller \& Freeman (1981). The most convincing evidence of a protective effect of fibre comes from the International Agency for Research on Cancer (IARC) Intestinal Microbiology Group (1977), who studied two Scandinavian populations and demonstrated that a lower incidence of colorectal cancer in rural Finland was associated with a significantly higher intake of total dietary fibre. Stool weights were also significantly heavier in the population with the lower incidence of colorectal cancer. More recent studies show that this inverse association is true over a wider range of populations and that there is a trend whereby the intake of dietary pentosans and cellulose, but not hexose or uronic acid (pectin) fibre fractions, is related to a lower incidence of colorectal cancer (IARC, unpublished results). This inverse association of colorectal cancer with certain components of fibre has also been shown in Britain (Bingham et al.1979). Animal colonic carcinogenesis studies support the epidemiological information. In rats, the ingestion of cellulose has been shown to have a protective effect on 1,2-dimethyl hydrazine-induced colonic neoplasms (Freeman et al. 1980), whilst pectin does not exert a protective effect and may even increase carcinogenesis (Bauer et al. 1981).

It has been proposed (Thornton, 1981) that the effects of fibre on carcinogenesis may be mediated by alterations in stool $\mathrm{pH}$. Although eating six oranges daily significantly lowers the stool pH (Walker et al. 1979), the ingestion of wheat bran does not appear to exert this effect (Stephen \& Cummings, 1981). The present study was performed in order to investigate the effects of the individual fibre components, pectin, cellulose and lignin, on stool $\mathrm{pH}$, transit time and wet weight.

\section{METHODS}

Subjects

Three groups of ten subjects each were investigated over an 8 week period. All subjects were healthy volunteers who gave their informed consent to participate in the study, which was

$$
\text { * For reprints. }
$$


approved by the Wellington Hospital Board Ethical Committee. The pectin group comprised two male medical students and eight female postgraduate nurses (mean age 30.9 (SD 7.9) years). The cellulose group was made up of four male medical students, two female medical students and four female postgraduate nurses (mean age 23.9 (SD 1.9) years). The lignin group consisted of two male medical students, two female medical students, five female postgraduate nurses and one female technical officer (mean age $28 \cdot 3$ (SD 7.8) years).

\section{Experimental design}

For each group, a cross-over design consisting of two periods of 4 weeks was used. Each subject acted as his (her) own control taking either pectin, cellulose or lignin for one period only (test period) and consuming his (her) normal diet during the other period (control period). Subjects were paired according to sex and occupation, then randomly allocated to the groups and periods, so that the number of males and females receiving the supplement first was the same as the number entering the control period first and the number of students and nurses was similarly distributed.

\section{Diets}

Subjects were instructed to maintain their normal diet throughout the study and not to take any medication. Detailed dietary records as recommended by Bingham \& Cummings (1980) were kept over the 8 week period. Food scales, measuring cylinders and flasks were distributed and every item of food or drink taken was weighed or measured and entered in a note book. The dietary records were supervised by a dietitian and analysed to ensure that there was no discrepancy in food patterns between the control and the test periods. Baseline dietary fibre intakes for the two periods were obtained using food tables (Holloway et al. 1977; Paul \& Southgate, 1978; Southgate, 1978). Subjects, wearing light indoor clothing, were weighed immediately before the study and at the end of both the control and test periods on the same scales.

Pure pharmaceutical citrus pectin with a methoxyl content of $93 \mathrm{~g} / \mathrm{kg}$ dry weight (Yakhin Canning Company Ltd, Tel Aviv) and $99.5 \%$ pure $\alpha$-cellulose fibre (Sigma Chemical Company, Missouri) were used for the study. Pure Aspen autohydrolysis lignin was supplied by Professor Morris Wayman and Stake Technology Ltd, Ontario. Before the test period, each subject was given a bag containing $420 \mathrm{~g}$ of the supplement and instructed to take a total of $15 \mathrm{~g} / \mathrm{d}$ (a measure of $5 \mathrm{~g}$ with each meal) for $28 \mathrm{~d}$. The pectin, cellulose or lignin was to be mixed with the usual food or drink taken at mealtimes in any way acceptable to the subjects. Any supplement left over at the end of the test period was collected and weighed. If the supply was exhausted before the end of the test period, more was distributed. The amounts of pectin, cellulose and lignin taken by each subject and the side-effects experienced are shown in Table 1. Subjects experienced great difficulty in taking the full amount of pectin because of its gelling properties, whilst lignin proved to be extremely unpalatable. One subject in the pectin group ingested a mean daily supplement of $3.4 \mathrm{~g}$ only and another subject in the lignin group took a mean of $6.7 \mathrm{~g}$ supplement/d. Exclusion of these subjects from the analyses did not alter the results. Cellulose was well tolerated and the lowest mean daily supplement taken by a subject was $11 \cdot 2 \mathrm{~g}$.

\section{Stool measurements}

At the end of both the control and test periods, the single stool transit time, using the radio-opaque marker pellet method described by Cummings \& Wiggins (1976) was measured. A $48 \mathrm{~h}$ stool collection was made into plastic bags, stored in a tin at $4-6^{\circ}$, and a $24 \mathrm{~h}$ wet stool weight obtained. Faecal $\mathrm{pH}$ was determined by immersion of a combination $\mathrm{pH}$ electrode (Orion) into three regions of each stool and taking a mean of the measurements 
Table 1. Mean amounts of pectin, cellulose and lignin taken $(g / d)$ by individual human subjects and reported side-effects

\begin{tabular}{|c|c|c|c|c|c|c|c|c|c|c|c|}
\hline \multicolumn{4}{|c|}{ Pectin } & \multicolumn{4}{|c|}{ Cellulose } & \multicolumn{4}{|c|}{ Lignin } \\
\hline \multicolumn{2}{|c|}{ Subject } & \multirow[b]{2}{*}{$\begin{array}{c}\text { Mean } \\
\text { amount }\end{array}$} & \multirow[b]{2}{*}{$\begin{array}{l}\text { Reported } \\
\text { side-effects }\end{array}$} & \multicolumn{2}{|c|}{ Subject } & \multirow[b]{2}{*}{$\begin{array}{l}\text { Mean } \\
\text { amoun }\end{array}$} & \multirow[b]{2}{*}{$\begin{array}{l}\text { Reported } \\
\text { side-effects }\end{array}$} & \multicolumn{2}{|c|}{ Subject } & \multirow[b]{2}{*}{$\begin{array}{c}\text { Mean } \\
\text { amount }\end{array}$} & \multirow[b]{2}{*}{$\begin{array}{l}\text { Reported } \\
\text { side-effects }\end{array}$} \\
\hline Sex & $\begin{array}{c}\text { Age } \\
\text { (years) }\end{array}$ & & & Sex & $\begin{array}{c}\text { Age } \\
\text { (years) }\end{array}$ & & & Sex & $\begin{array}{c}\text { Age } \\
\text { (years) }\end{array}$ & & \\
\hline o & 21 & $15 \cdot 0$ & - & $a$ & 21 & $16 \cdot 0$ & - & 우 & 22 & $14 \cdot 2$ & Laxative \\
\hline $0^{*}$ & 21 & $11 \cdot 0$ & - & 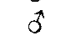 & 23 & $16 \cdot 3$ & - & q & 24 & $11 \cdot 2$ & - \\
\hline$q$ & 26 & $15 \cdot 0$ & - & $\hat{b}$ & 25 & 8.8 & - & $q$ & 43 & 6.7 & Flatulence \\
\hline$q$ & 28 & $9 \cdot 0$ & Laxative & $a$ & 23 & $16 \cdot 0$ & - & $q^{+}$ & 42 & $14 \cdot 2$ & - \\
\hline q & 30 & $15 \cdot 0$ & Constipation & q & 21 & $11 \cdot 2$ & - & $\hat{0}$ & 24 & $9 \cdot 8$ & - \\
\hline † & 42 & $12 \cdot 3$ & Constipation & $\begin{array}{l}+ \\
+ \\
+\end{array}$ & 23 & $16 \cdot 4$ & - & o & 23 & 16.0 & - \\
\hline 우 & 41 & 12.9 & - & $q$ & 25 & $13 \cdot 9$ & $\begin{array}{l}\text { Nausea, } \\
\text { retching }\end{array}$ & q & 23 & $14 \cdot 2$ & Constipation \\
\hline q & 27 & $3 \cdot 4$ & 'Intolerable' & 우 & 25 & 13.9 & $\begin{array}{l}\text { Cramps, } \\
\text { urgency }\end{array}$ & q & 28 & $9 \cdot 3$ & Constipation \\
\hline P & 40 & $15 \cdot 0$ & Nausea & q & 26 & $15 \cdot 0$ & - & 우 & 28 & $14 \cdot 5$ & $\begin{array}{l}\text { Flatulence, } \\
\text { diarrhoea }\end{array}$ \\
\hline 우 & 33 & $10 \cdot 4$ & Heartburn & $q$ & 21 & $19 \cdot 7$ & - & q & 26 & $12 \cdot 2$ & Satiety \\
\hline Mean & & 11.9 & & & & $14 \cdot 7$ & & & & $12 \cdot 2$ & \\
\hline SD & & 3.7 & & & & $3 \cdot 0$ & & & & $2 \cdot 9$ & \\
\hline
\end{tabular}

using a Radiometer $\mathrm{pH}$ meter. Stools were not homogenized or diluted. The coefficient of variation for ten probes with this method was $2 \%$.

\section{Statistics}

An analysis of variance for a two-period cross-over design was used to calculate the $F$-values with their respective degrees of freedom. Correlation coefficients were calculated and their statistical significance was determined using a two-tailed $t$ test. A two-tailed $t$ test was also used to test for inter-group and inter-sex differences. The level of significance used for all tests was $P<0.05$.

\section{RESULTS}

\section{Body-weight and dietary fibre intake}

Neither the mean body-weight nor the mean basal dietary fibre intakes differed significantly between the control and test periods for any of the groups. The mean (SD) basal dietary fibre intakes for the control and test periods respectively were: pectin group $18.0(3.5) \mathrm{g}$, $22.9(8 \cdot 4) \mathrm{g}$; cellulose group $21 \cdot 3(6 \cdot 6) \mathrm{g}, 23.9(15.9) \mathrm{g}$; lignin group $21.5(5 \cdot 1) \mathrm{g}, 20 \cdot 2(5 \cdot 5) \mathrm{g}$.

\section{Comparison of groups and sexes}

There was no statistically significant difference in the mean stool $\mathrm{pH}$, transit time or weight for the control periods of the pectin, cellulose or lignin groups. Over-all comparison of the sexes did not show a statistically significant difference between males and females for stool $\mathrm{pH}$ or transit time, but revealed a highly-significant difference $(P<0.01)$ between the $24 \mathrm{~h}$ wet stool weights of males (mean 188.7 (SD 41.5) g) and females (mean 115.7 (SD 54.0) g). This may reflect the statistically significant $(P<0.001)$ difference in daily energy intake between males (mean 11.6 (SD 3.0) MJ) and females (mean 7.5 (SD 2.0) $\mathrm{MJ}$ ) and, in particular, the mean carbohydrate intake, which was 301.4 (SD 102.9) $\mathrm{g}$ for males and 200.0 (sD 59.2) $\mathrm{g}$ for females. There was no significant difference between the sexes in basal dietary fibre intakes. 
Table 2. Stool pH, transit time and weight for control and test periods for groups of human subjects receiving pectin, cellulose and lignin

(Mean values with their standard deviations)

\begin{tabular}{|c|c|c|c|c|c|c|}
\hline \multirow[b]{2}{*}{ Experimental period... } & \multicolumn{2}{|c|}{ Pectin } & \multicolumn{2}{|c|}{ Cellulose } & \multicolumn{2}{|c|}{ Lignin } \\
\hline & Control & Test & Control & Test & Control & Test \\
\hline \multicolumn{7}{|l|}{ Stool pH } \\
\hline Mean & $6 \cdot 51$ & 6.53 & $6 \cdot 38$ & $6 \cdot 12^{*}$ & $6 \cdot 34$ & $6 \cdot 25$ \\
\hline SD & 0.57 & 0.42 & 0.25 & 0.43 & $0 \cdot 30$ & 0.44 \\
\hline \multicolumn{7}{|c|}{ Single stool transit time (h) } \\
\hline Mean & $51 \cdot 1$ & $57 \cdot 4$ & $55 \cdot 3$ & $40 \cdot 4^{* *}$ & $50 \cdot 1$ & $40 \cdot 5$ \\
\hline SD & $23 \cdot 5$ & $14 \cdot 3$ & $19 \cdot 7$ & $12 \cdot 7$ & $22 \cdot 1$ & $17 \cdot 4$ \\
\hline \multicolumn{7}{|l|}{$24 \mathrm{~h}$ wet stool wt $(\mathrm{g})$} \\
\hline Mean & 134.9 & $118 \cdot 7$ & $132 \cdot 6$ & $207 \cdot 8^{*}$ & $138 \cdot 7$ & 176.7 \\
\hline $\mathrm{SD}$ & $66 \cdot 5$ & $79 \cdot 9$ & $65 \cdot 6$ & $94 \cdot 2$ & $53 \cdot 6$ & $78 \cdot 0$ \\
\hline
\end{tabular}

Mean values were significantly different from control values $* P<0.05 ;{ }^{* *} P<0.01$.

Table 3. Correlation coefficients between stool $p H$ and stool transit time, stool $p H$ and stool weight, and stool transit time and stool weight

\begin{tabular}{|c|c|c|c|c|c|c|}
\hline \multirow[b]{2}{*}{$\begin{array}{l}\text { Experimental period... } \\
\text { Fibre component }\end{array}$} & \multicolumn{2}{|c|}{$\begin{array}{l}\text { Stool } \mathrm{pH} v \text {. single stool } \\
\text { transit time }(\mathrm{h})\end{array}$} & \multicolumn{2}{|c|}{$\begin{array}{l}\text { Stool pH v. } 24 \mathrm{~h} \\
\text { wet stool wt. (g) }\end{array}$} & \multicolumn{2}{|c|}{$\begin{array}{l}\text { Single stool transit } \\
\text { time (h) } y .24 \mathrm{~h} \\
\text { wet stool wt (g) }\end{array}$} \\
\hline & Control & Test & Control & Test & Control & Test \\
\hline Pectin & $0 \cdot 37$ & $0 \cdot 21$ & 0.24 & -0.33 & $-0 \cdot 12$ & $-0 \cdot 11$ \\
\hline Cellulose & $0.80^{*}$ & 0.56 & $-0.71^{*}$ & 0.24 & $0.75^{*}$ & -0.14 \\
\hline Lignin & $0.65^{*}$ & $0 \cdot 31$ & -0.15 & -0.33 & $-0 \cdot 36$ & -0.47 \\
\hline
\end{tabular}

Values were statistically significant: ${ }^{*} P<0.05$.

\section{Stool $p H$}

As shown in Table 2, pectin did not alter the mean stool $\mathrm{pH}$ significantly whereas cellulose resulted in a fall in stool $\mathrm{pH}$ in nine of the ten subjects. Analysis of variance revealed a carry-over effect whereby a significantly lower mean $\mathrm{pH}$ was present at the end of the control period if this period followed the test period rather than being the initial period. Lignin lowered the mean $\mathrm{pH}$ but the change was not statistically significant.

\section{Stool transit time}

The effect of the fibre components on mean stool transit time is given in Table 2. For pectin, the transit time was raised but the change was not statistically significant. In contrast, all subjects but one showed a more rapid stool transit time after the ingestion of cellulose, with a decrease in the mean of $27 \%$ which was significant $(P<0.01)$. There was also a carry-over effect observed as the mean transit time at the end of the control period was still significantly shorter if the control period followed the test period rather than vice versa. Lignin decreased the mean stool transit time by $20 \%$ but this change was not statistically significant. 


\section{Stool weight}

When compared with controls, increasing the consumption of pectin did not significantly increase stool weight. However, the increase in stool weight of $57 \%$ caused by cellulose was significant $(P<0.05)$. The order of the two periods (test, control $v$. control, test) had no significant effect on stool weight. Lignin resulted in an increase of $27 \%$ in the $24 \mathrm{~h}$ wet stool weight, but this change was not statistically significant (Table 2).

\section{Correlations between stool characteristics}

Correlation coefficients between stool $\mathrm{pH}$ and transit time, stool $\mathrm{pH}$ and weight, and stool transit time and weight for both the control and test periods are given in Table 3. Significant correlations were observed in the control periods between stool $\mathrm{pH}$ and transit time for both the cellulose and lignin groups, but only for the cellulose group between stool $\mathrm{pH}$ and weight, and transit time and weight. After fibre component supplementation for 4 weeks, no significant correlations were observed.

\section{DISCUSSION}

The present study shows that purified $\alpha$-cellulose had significant effects on stool characteristics whilst highly methoxylated citrus pectin and Aspen autohydrolysis lignin did not. The mean daily addition of either $12 \mathrm{~g}$ pectin or $12 \mathrm{~g}$ lignin to the diet did not result in any statistically significant change in stool $\mathrm{pH}$, transit time or weight, whereas cellulose at a mean dose of $15 \mathrm{~g} / \mathrm{d}$ caused significant changes in all these measurements. The amounts of pectin and lignin taken were the maximum tolerated by the subjects and although it could be argued that the differences between the pectin and lignin and the cellulose effects were due to the lower doses of the first two components, this seems unlikely as the difference in dosage was small, and analysis of the results after exclusion of the subjects taking the lowest doses of fibre supplement did not alter the outcome. It could also be argued that the cellulose group differed from the pectin and lignin groups as there were four males in the cellulose group compared with two in each of the other groups. Despite males having over-all a significantly greater stool weight in the control periods compared with females, this could not bias the results of the study as each subject acted as his or her own control and gender was taken into account before allocation to periods.

The authors are not aware of any previous human studies on the faecal effects of lignin. Previous studies with pectin have produced conflicting results. No significant change in faecal mass, even after the addition of $40-50 \mathrm{~g}$ pectin/d, was reported by Miettinen \& Tarpila (1977), whilst Durrington et al. (1976) demonstrated a significant increase in wet stool weight but no alteration of stool transit time at a dose of $12 \mathrm{~g} / \mathrm{d}$. Jenkins et al. (1978) reported that pectin delayed small bowel transit time. Cellulose, in comparison, has been shown previously to increase wet stool weight (Eastwood et al. 1973; Slavin \& Marlett 1980; Spiller et al. 1980) and to decrease transit time (Spiller et al. 1980). The effect of these components on stool $\mathrm{pH}$ has not been reported except in hamsters, in which lignin did not alter the pH (Rotstein et al. 1980). Faecal pH can be lowered, however, by the addition of six oranges daily to the diet (Walker et al. 1979), which would correspond to 8-12 g cellulose, given that a peeled orange comprises $14 \mathrm{~g}$ cellulose $/ \mathrm{kg}$ edible fruit (Holloway $e t$ al. 1977). A $30 \mathrm{~g}$ supplement of wheat bran/d would only contribute $3 \mathrm{~g}$ cellulose, which may explain the inability of bran to lower stool pH (Stephen \& Cummings, 1981) if dietary cellulose is an important determinant of stool $\mathrm{pH}$.

The contrasting effects of pectin, cellulose and lignin on stool characteristics may be related to the different digestion of the fibre components in the gut. Pectin is completely 
digested (Cummings et al. 1979) whilst $22.4 \%$ of ingested cellulose is excreted unchanged in the faeces (Holloway et al.1978). In contrast, over $80 \%$ of lignin can be recovered from the faeces (Kelsay et al. 1981). Residual cellulose could exert a water-holding effect and hence alter stool transit time and weight, but this would not explain the change in stool $\mathrm{pH}$. If the response were related to the production of volatile short chain fatty acids, then totally fermentable components such as pectin would be expected to cause even greater changes (Cummings, 1981) though perhaps the slower, more prolonged digestion of cellulose in the colon may be important. However, Stephen \& Cummings (1980) have shown that cabbage fibre alters colonic function by stimulating microbial growth. If this were true for cellulose, then the carry-over effect seen in the present study, whereby the effects of cellulose on stool $\mathrm{pH}$ and transit time persisted for at least $28 \mathrm{~d}$ after taking the supplement, could be explained in terms of altered bacterial flora.

An inverse relationship between daily stool weights and transit times has been documented previously (Burkitt et al . 1972), although the IARC Intestinal Microbial Group study (1977) did not find the expected correlation. In the present study there was no consistent, statistically significant correlation between any of the stool characteristics. Although the number of subjects studied was small, this may indicate that stool $\mathrm{pH}$, transit time and weight can vary independently. It is interesting that the correlation coefficient between stool $\mathrm{pH}$ and transit time after cellulose supplementation was 0.57 , which just failed to reach statistical significance $(P=0.09)$, considering that cellulose exerted a prolonged effect on both factors.

As individual fibre components have differing effects on stool characteristics, these factors should be taken into consideration when evaluating the possible role of dietary fibre in colorectal disease. Analysis of the types of dietary fibre components consumed may be pertinent to our understanding of the aetiology of colorectal cancer.

This study was supported by a Medical Research Council of New Zealand Grant (no. 81/34). The authors wish to thank Professor Morris Wayman and Stake Technology Ltd, Ontario, for the supply of lignin.

\section{REFERENCES}

Bauer, H. G., Asp, N. G., Dahlqvist, A., Fredlund, P. E., Nyman, M. \& Oste, R. (1981). Cancer Research 41, 2518-2523.

Bingham, S. \& Cummings, J. H. (1980). In Medical Aspects of Dietary Fiber, pp. 261-284 [G. A. Spiller and R. M. Kay, editors]. New York: Plenum.

Bingham, S., Williams, D. R. R., Cole, T. J. \& James, W. P. T. (1979). British Journal of Cancer 40, $456-463$.

Burkitt, D. P., Walker, A. R. P. \& Painter, N. S. (1972). Lancet ii, 1408-1411.

Cummings, J. H. (1981). Gut 22, 763-779.

Cummings, J. H., Southgate, D. A. T. \& Branch, W. J. (1979). British Journal of Nutrition 41, 477-485.

Cummings, J. H. \& Wiggins, H. S. (1976). Gut 17, 219-223.

Durrington, P. N., Manning, A. P., Poolton, C. H. \& Hartog, M. (1976). Lancet ii, 394-396.

Eastwood, M. A., Kirkpatrick, J. R., Mitchell, W. D., Bone, A. \& Hamil, T. (1973). British Medical Journal 4, 392-394.

Freeman, J. H., Spiller, G. A. \& Kim, Y. S. (1980). Cancer Research 40, 2661-2665.

Holloway, W. D., Tasman-Jones, C. \& Lee, S. P. (1978). American Journal of Clinical Nutrition 31, $927-930$.

Holloway, W. D., Tasman-Jones, C. \& Maher, K. (1977). New Zealand Medical Journal 85, 420-423.

International Agency for Research on Cancer, Intestinal Microbiology Group (1977). Lancet ii, $207-211$.

Jenkins, D. J. A., Wolever, T. M. S., Leeds, A. R., Gassull, M. A., Haisman, P., Dilawari, J., Goff, D. V., Metz, G. L. \& Alberti, K. G. M. M. (1978). British Medical Journal 1, 1392-1394.

Kelsay, J. L., Goering, H. K., Behall, K. M. \& Prather, E. S. (1981). American Journal of Clinical Nutrition 34, 1849-1852.

Miettinen, T. A. \& Tarpila, S. (1977). Clinica Chimica Acta 79, 471-477.

Paul, A. A. \& Southgate, D. A. T. (1978). McCance and Widdowson's The Composition of Foods, 4th ed. London: H.M. Stationery Office.

Rotstein, O. D., Kay, R. M., Wayman, M. \& Strasberg, S. M. (1980). Gastroenterology 79, 1247 (Abstract). 
Slavin, J. L. \& Marlett, J. A. (1980). American Journal of Clinical Nutrition 33, 1932-1939.

Southgate, D. A. T. (1978) American Journal of Clinical Nutrition, Supplement 31, 107-110.

Spiller, G., Chernoff, M. C., Hill, R. A., Gates, J. E., Nassar, J. J. \& Shipley, E. A. (1980). American Journal of Clinical Nutrition 33, 754-759.

Spiller, G. A. \& Freeman, H. J. (1981). American Journal of Clinical Nutrition 34, 1145-1152.

Stephen, A. M. \& Cummings, J. H. (1980). Nature 284, 283-284.

Stephen, A. M. \& Cummings, J. H. (1981). Gastroenterology 80, 1294 (Abstract).

Thornton, J. R. (1981). Lancet i, 1081-1082.

Walker, A. R. P., Walker, R. F. \& Segal, I. (1979). South African Medical Journal 55, 495-498. 